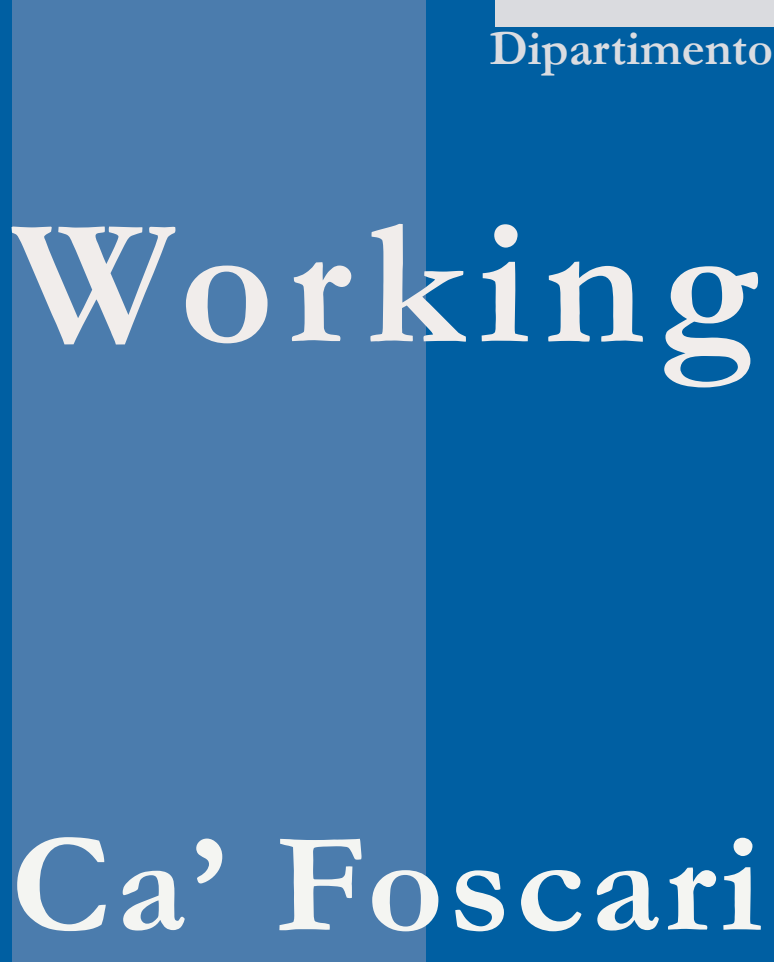

Scienze Economiche

Paper

Department

of Economics

University of

Venice

Giuseppe Tattara

Emerging Hubs in

Central-Eastern Europe,

Trade Blocs and Supply

Chain Restructuring 


\title{
Emerging Hubs in Central-Eastern Europe, Trade Blocs and Supply Chain Restructuring
}

\author{
Giuseppe Tattara \\ University of Venice
}

First Draft: November 2006

\begin{abstract}
Many European countries have faced the erosion of the competitive advantage in the international market with a mixed stratgy of productivity increase at home and labour cost reduction abroad, through the international fragmentation of production and subcontracting in low wage countries. Italy in particular, has delocalized segments of its industrial production in Eastern Europe. The advantage of delocalization abroad - with particular reference to East European countries - is due to the low cost of labour, depends from the capability to transmit information efficiently and the availability of a complete supply-type blueprint in the receiving country.The paper discusses the prospects open to Italia apparel firms and presents a case study dealing with the development of outsourcing by the Benetton group in the last decades.
\end{abstract}

\section{Keywords}

Vertical Integration, Global Organization of Production, Macroeconomics

\section{JEL Codes}

F23, L16, L22, L23

\author{
Address for correspondence: \\ Giuseppe Tattara \\ Department of Economics \\ Ca' Foscari University of Venice \\ Cannaregio 873, Fondamenta S.Giobbe \\ 30121 Venezia - Italy \\ Phone: (++39) 0412349148 \\ Fax: (++39) 0412349176 \\ e-mail::tattara@unive.it
}

This Working Paper is published under the auspices of the Department of Economics of the Ca' Foscari University of Venice. Opinions expressed herein are those of the authors and not those of the Department. The Working Paper series is designed to divulge preliminary or incomplete work, circulated to favour discussion and comments. Citation of this paper should consider its provisional character.

$\begin{aligned} \begin{array}{r}\text { The Working Paper Series } \\ \text { is availble only on line }\end{array} & \begin{array}{l}\text { Department of Economics } \\ \text { Ca' Foscari University of Venice }\end{array} \\ \text { (www.dse.unive.it/pubblicazioni) } & \text { Cannaregio 873, Fondamenta San Giobbe } \\ \text { For editorial correspondence, please contact: } & \text { 30121 Venice Italy } \\ \text { wp.dse@unive.it } & \text { Fax: }++390412349210\end{aligned}$




\section{Emerging Hubs in Central-Eastern Europe, Trade Blocs and Financial Co-operation}

Globalization refers to the generalized expansion of international economic activity, which includes increased international trade, growth of international investment, foreign investment, international migration and increased spreading of technology among countries. Globalization is the increasing integration of markets for goods, services, labor, and capital. The term is commonly used to describe the ongoing, multidimensional process of worldwide change and is here referred specifically to the economic context.

The globalization process in recent years has been subject to a great increase but is not a new phenomenon. Economic historians have recalled to us that also during the 19th century a large globalization process had taken place in the world, similar in magnitude and pervasiveness to that we are experiencing to-day.

The main points discussed by historians concern first of all the increase in the merchandise flows ${ }^{1}$. Merchandise flows have increased very rapidly during the 19th century as well ${ }^{2}$, due to the decline of transport costs (sea routes) and the liberal tariff policies followed by UK and other European countries, at least before the 80's of the 19th century (O'Rourke and Williamson, 1999; 2002; Taylor, 2002). Merchandise flows were raw material flows against manufacture flows, mainly raw materials coming from the overseas territories.

Huge migration flows are also a common feature. Migration flows were in reality much bigger in the 19th century than to day, due to the present restrictive policies of many industrial countries ${ }^{3}$. Emigrant flows form the poorest to the richer countries: in the 19th century European emigrants flowed towards US, Canada, Argentina, that were comparatively richer than many European countries at that time (Zlotnik, 1999; O’Rourke, 2002).

\footnotetext{
${ }^{1}$ In the nineteenth century the ratio of world trade (exports+imports) to output had risen from less than two percent to around 16 percent; since the growth rate of world output in the nineteenth century was much slower than in the twentieth century, it was during the nineteenth century that the growth rate of trade-to-output ratios in the world reached its alltime peak (Taylor,2002).

${ }^{2}$ Feenstra (1988) has argued that the merchandise flow increase should be related to the industrial value added and not to PIL. PIL in modern societies is in large measure the result of the service sector expansion so the ratio between merchandise export value and PIL undervalue the "real" expansion of trade.

${ }^{3}$ For a summary, see O’Rourke (2002)
} 
Of course public finance, in its relations with money and fiscal policy, sets the institutional stage for international as well as domestic market transactions. Currency stability, either because of the gold standard or because shadowing gold, was the norm for the core countries of the system. Defaulting on foreign debt was not considered a feasible option, at least in Europe, and in such a context large capital flows sustained the merchandise flows and promoted economic development in many newcomer countries. Capital flows, it may be, are comparable in magnitude now and then (Obstfeld and Taylor, 1998), although they are different under many respects and the context in which the two globalizations have taken place is rather different. In the 19th century capital flows were mainly foreign direct investments, originating in London, surging when domestic investments weakened (Epstein, 1982; Fenoaltea, 1988: 605). Short-term capital flows were not relevant, so the prevalence was about long-term flows constituted by both government debt and foreign direct investments (Fishlow, 1985).

A striking feature of the current situation is the huge deficit on the current account of the worlds dominant country, the United States, which is partly being financed with surpluses in the current and capital account of developing countries, especially those in developing Asia (Chandrasekhar, Ghosh, 2004). The current account deficit in the US has widened continuously since the mid-1990s, resulting in an overall deficit for all advanced economies, despite the fact that every one of them has shown surpluses in almost all those years. On the other hand, during this period developing countries as a group have seen a transformation of their current account deficits into surpluses. Many of these developing countries were recipients of large capital inflows-in the form of foreign direct investment (mainly of a financial nature), portfolio capital and debt, resulting in surpluses on the capital account. Together these current and capital account surpluses were adding to their reserves, which in turn were being invested in dollar denominated financial assets, thereby financing in part the US deficit. A feature that contrasts with common sense that would require capital flowing where it is most needed, in the low income countries, but that shares some peculiar character of the functioning of the "gold exchange standard" as devised by Keynes in his Indian Currency and Finance book (1913). Keynes' thesis was that the empire of India was kept by the British on a silver standard in order to ease Indian export of primary commodities and raw materials and to generate an export surplus that was invested in London, in government bonds or deposits within the banking system. At the end Indian surplus considerably helped in stabilizing the gold standard although the system was not conducive to Indian economic growth (De Cecco, 1997;70).

The nature of foreign investments is also profoundly different now and then. In the 19th century foreign direct investments were mainly directed towards the exploitation of natural resources, tended to build enclave economies, run by subsidiaries of big companies at home, so that the relation between the foreign company and the domestic one was direct and hierarchical. To day a 
large part of merchandise flows concerns components and parts: intraindustry trade accounts for the most dynamic and relevant part of trade global flows (Feenstra and Hanson, 1997). This is the result of a process of governance of the productive value chains at the global level increasingly based on subcontracting abroad a whole set of production sequences. Subcontracting can be accompanied by foreign direct investment, but in many situations foreign direct investment, and the connected capital movements, are limited and sub-contracting to local firms is the relevant option. Subcontracting can be considered as a different way of investing abroad, but some character of sub-contracting makes it very different from direct investment.

The object of the present delocalization process is not the control of raw material supply and availability, as in the 19th century, but the need to face the competitive pressure on the international market by the industrial countries that started to delocalize in the past and now compete on the basis of a lower cost curve (Hummels, Rapoport and Yi, 1998; Kaminski and Ng, 2000).

\section{Trade Integration and Fragmentation of Production}

\subsection{Outsourcing and the Global Value Chain Governance}

Industrial countries are able to face the erosion of the competitive advantage in the international market by a mixed strategy of productivity increase at home and labour cost reduction abroad, through the international fragmentation of production.

Sub-contracting abroad is the result of the splitting of production into segments. This has taken place, in the first place, in the industrial countries where firms have increasingly used a network structure in order to reach a higher efficiency level, mainly in terms of reducing the organizational costs (Gereffi, Humphrey, Sturgeon, 2005).

Fundamental changes in the material logic of modern production - the appearance of new core technologies, the widespread diffusion of advanced technological capabilities and changes in the pattern of international competition, ubiquitous organisational technological and market uncertainty - have lead to a re-assessment of the production process at the global level.

The subcontracting system has undergone an evolution based on the diffusion of economies of scale by the small enterprises, due to the capacity of these firms to specialise in complex jobs. The growing need to have some suppliers who are able to act as independent sources of production and of innovative activity has changed the production structure in many western countries leading towards a network organization of production. In such a context small and medium size sub-contracting units take up large part of the value chains is by as economies of scale are - more correctly - referred to production phases rather than to the whole production lot. 
With production fragmentation, the advantage of delocalization abroad is explained by cost reduction, by the production volume, by the need to service new, faraway, markets.

Among the main disadvantages faced by delocalizing firms are the lack of a complete supply-type blueprint and the capacity of the outsourced firms to face complex products. This varies according to the commodities and to the countries concerned. Many firms in Asia offer to U.S. and European buyers a complete interface, involving vendor relationships, logistics and inventory control with subcontractors located in China, Japan and lower cost countries of Southeast Asia, while in East Europe the management and coordination of the flow of orders stays entirely within the foreign buyers and the supply blueprint presents several, crucial, bottlenecks.

Chain management in a continuously changing competitive environment requires the capability to transmit information efficiently, i.e. the possible recourse to electronic transmission and product standardization (modularity of complex products) and sub-contracting is accompanied by a process of standardization and codificability of the main manufacturing operations.

Due to low transport costs and to the information technology, subcontracting is profitable also if production lots are small (i.e. hundred of pieces of apparel, not thousands) and products are very variable in kind, although various anecdotal evidence points to the fact that face-to-face relations prove still to be very relevant, particularly for complex products and when time to market is important. There are costs in changing contractors, of course, and are related to the necessity to reduce the delivery time and to the contractor's fidelity, that is often required - beside the cost element - as a quality guarantee.

Apart from obvious similarities the present outsourcing framework is much different from the 19th century foreign direct investment framework and from the staple economy settling in which the foreign investment took place. In particular the merchandise flows related to outsourcing are very unstable due to the absence of sunk costs (sunk costs instead are a characteristic of direct investment) and sub-contracting solutions are likely to migrate towards new countries as far as new cost reduction opportunities open up.

Successful sub-contracting involves action by the governments, as it is often grounded on specific tariff arrangements. Typical is the Outward Processing Trade (OPT) provision, i.e. the possibility to import raw materials or components to be manufactured and exported in tariff exemption. This, in the post world war period, was introduced by the US under tariff article 807 and has been common practice for the European Union under the accession process (Finger, 1975; 1977). OPT has become an important instrument of trade policy in the EU in textiles and clothing industry, in footwear and other traditional sectors (Chakravarti, 1995; Finger, 1977) ${ }^{4}$.

OPT sub-contracting links low-cost producers in East European countries, in Mexico and the Caribbean, and buyers in the EU and in the USA respectively, enabling the latter to appropriate a greater share of surplus-

\footnotetext{
${ }^{4}$ The rules of origin accompanying such transactions provide the tariff preference on the reimported product only if produced from components of a specific origin.
} 
value than would be possible if production was located in high cost countries.

In the early nineties European firms were much less dependent from outsourcing than their US counterpart and large part of production was carried out domestically; to day the degree of outsourcing abroad between Europe and US - according to Tpi, one of the main world advisory companies on the field - is rather similar ${ }^{5}$. So recently Europe has paralleled the US in the governance of the global value chains, completing production abroad, whenever possible and profitable.

Outsourcing through subcontracting is more flexible than foreign direct investment, but perhaps more promising, as - and whether - it is able to mobilise a large amount of local resources and local manufacturing activities. The advantage of delocalizing through subcontracting is that low capital flows are required, although a huge amount of resources is mobilized - frequently mobilized through sub-contracting, particularly labour, are bigger than resources mobilized through foreign direct investments.

\section{I.2. Emerging Hubs in Central-Eastern Europe}

The collapse of the Soviet Union has been accompanied by a significant process of liberalisation in trade and investment towards East European countries. Direct foreign investments have clustered in some Eastern and Central Europe countries, more rapid in entering the reform process and politically stable, as Hungary, Cekia, Poland, but integration has significantly developed as firms in these countries have become part of the emerging global division of labour driven by fragmentation of production. Firms part of global production and distribution networks are not necessarily foreign-owned, but firms playing a role in a global network, connected by various kind of supply relations - from market to captive, modular, relational, hierarchical linkages (Gereffi, Humphrey, Sturgeon, 2005).

Production fragmentation at the global level occurs across national borders and thus triggers extra foreign trade flows. A portion of this trade is intrafirm trade, i.e., taking place among subsidiaries a multinational corporation, but outsourcing is the most significant form in which firms in Eastern Europe integrate into the world market. The part of foreign trade that can be directly attributed to fragmentation of production offers an opportunity to measure the importance of the process.

The intensification of trade between East Europe and the European Union has been accompanied by a significant growth in parts and intermediate merchandise trade flows. Trade in parts is highly concentrated in few items

\footnotetext{
5 The European outsourcing market is set to rival the US in terms of contract awards in 2004, according to independent sourcing advisory company, TPI. In its fourth quarter 'TPI Index' - an independent report on the sourcing market - reports that European outsourcing activity has significantly increased and approaches that of the US outsourcing market in contract volume.
} 
in both exports and imports. Moreover, there is a high degree of correspondence between imports and exports - their rankings only marginally diverge. In other words, large exports require large imports, which appears to suggest than within product groups production sharing takes place. Trade in motor vehicle parts is the largest item in both exports and imports. Telecommunication parts is the second largest item in Central and East Europe Countries imports of parts (Kaminski and Ng, 2000). Apparel and footwear exports are closely mirrored by textile and leather imports in the same exporting countries (Graziani 1995, 1998, 2001).

Among the several industries that take part in the global value chain we focus on the textile and clothing industry, one of the main productive sectors in the Italian economy ${ }^{6}$. This is an important sector in the European manufacturing industry with a turnover in 2002 of over $€ 200$ billion produced in roughly 177,000 enterprises employing more than 2 million people (excluding the EU enlargement in May 2004). Textiles and clothing account for around $4 \%$ of total manufacturing value added and $7 \%$ of manufacturing employment in the EU-15. While, on their home market, EU operators are faced with intense (and increasing) competition from all over the world, European industry remains competitive due competitive strengths such as innovation, quality, creativity, design or fashion and to higher productivity generated by delocalization. EU industry managed to export, by the end of the $90 \mathrm{~s}$, around $17 \%$ of its turnover to third country markets, which made it the second largest world exporter of textile and clothing products after China.

In the last fifteen years EU textile and clothing industries have undergone a continuous restructuring process, due to competition from the low wage countries and this has lead to the loss of 655.000 jobs from 1995 to 2003 in the EU-15. The Uruguay Round Agreement on Textiles and Clothing has set deadlines for removal of quantitative restrictions on suppliers to the EU finally accomplished by 2005 - and has implied a continuing increase in international competitive pressures on the textile and clothing market. Large part of production, mainly relating to large batches and more standard items has moved to East Europe countries (Bulgaria, Rumania and Poland) and to the Mediterranean basin countries (Turkey, Morocco and Tunisia). EU manufacturers prefer those countries over some Asian countries with even lower wage rates (such as Vietnam, India or China) due to their geographical proximity and their higher quality standards. Thus, EU companies delocalizing in Eastern Europe remain able to respond quickly to changing market demands, and can more easily maintain control over the management and quality of the outsourced operation.

\footnotetext{
${ }^{6}$ Within the EU15 the most important centre of the textile and clothing sector is Italy accounting in 1999 for 31\% of EU15 activity as measured by a composite index derived from the average figures for national shares of EU15 turnover, value added and employment (Euratex, 2000). Next, at a distance, came the United Kingdom (15\%), Germany (14\%), France (13\%), Spain (9\%), Portugal (6\%), Belgium (4\%), Greece, Austria and the Netherlands (2\% each) and Denmark, Finland, Ireland and Sweden (1\% each).
} 
Different EU countries have followed different outsourcing strategies. UK, Sweden, Holland, whose markets are dominated by large retailers, mainly buyers at the international level, have oriented their outsourcing strategies towards China and the Far East while other countries as Italy, France and Germany import large commodity batches from the closest countries (Romania, Turkey, Tunisia and Morocco) and purchases are directly controlled by the domestic buyers.

In apparel production outsourcing takes place mainly in two ways, full package and outward subcontracting. With full package agreements the leading firm purchases a manufactured product from a supplier (most likely from a supply chain) and the supplier provides for the finished product, starting from raw materials and accessories. Most of the time the leading firm provides the design. Outward subcontracting agreement means that raw materials or semi-finished products are outsourced abroad for some completion phases, most of the time taking advantage of the special tariff regime.

Large part of the delocalization strategy towards East Europe is based on outward processing trade: large apparel exports require large textile imports or imports of unfinished items, and the appearance of the same low wage countries as important textile importers and apparel exporters, is a clear sign that in apparel outsourcing takes place at a large scale (table 1: Turkey, Rumania, Tunisia, Poland). Apparel imports China, India and Bangladesh concern instead ready to sell products, manufactured with tissues and accessories produced in Eastern Asia, where a huge supply variety is available (Crestanello and Dalla Libera, 2003).

Outward processing operations are planned well in advance, the supplier organize the (almost) entire manufacturing process, the risk is borne by the head of the chain; a heavy organization by the leading firm due to the governance of the chain, purchase of raw materials, sending of accessories and the close monitoring of the entire manufacturing process is required. Full package relations are usually part of a global chain that extends faraway, to East Asia, while subcontracting has a more regional horizon. For example outward subcontracting relations for the US concern Mexico and the Caribbean, for Europe mainly North Africa and Eastern Europe, for Japan mainly other low cost areas of the same region.

Table 1. European Union (-15) trade per country according to value magnitude in 2003, millions $€$

\begin{tabular}{|l|r|l|r|}
\hline & Apparel imports & & Textile exports \\
\hline China & 9631 & USA & 2559 \\
\hline Turkey & 7150 & Poland & 2076 \\
\hline Romania & 3634 & Rumania & 2027 \\
\hline Bangladesh & 3054 & Tunisia & 1460 \\
\hline Tunisia & 2709 & Turkey & 1439 \\
\hline India & 2464 & Morocco & 1326 \\
\hline Hong Kong & 2017 & Cekia & 1149 \\
\hline Poland & 1459 & Switzerland & 1041 \\
\hline
\end{tabular}

Source: Eurostat 
Table 2. Hourly compensation per employee in manufacturing, $€$

\begin{tabular}{|l|r|r|r|}
\hline & 1996 & 2000 & 2003 \\
\hline EU (15 countries) & 19.14 & 22.73 & 24.53 \\
\hline Germany & 24.26 & 25.68 & 27.93 \\
\hline Spain & 14.43 & 14.22 & $14.21^{\circ}$ \\
\hline France & 22.30 & 25.00 & 27.70 \\
\hline Italy & & & $19.99^{*}$ \\
\hline Poland & 2.95 & 4.48 & 4.70 \\
\hline Portugal & 7.18 & 8.35 & 9.21 \\
\hline Bulgaria & & 1.23 & 1.39 \\
\hline Romania & & 1.41 & $1.67 *$ \\
\hline
\end{tabular}

Source: Eurostat

$*=2002 ;^{\circ}=$ provisional

The OPT, launched in 1995 with the EU's support, has become an avenue for improving the competitiveness of EU's clothing industry and has gained much importance recently in East Europe countries. Labour costs, less than 1/10 in relation to EU-15 (table 2), the relatively skilled workforce and geographical proximity have stimulated the process of delocalization of textiles and clothing production from EU to East Europe ${ }^{7}$. China hourly compensation cost estimated by BLS is still lower; around $1 \$$ in urban manufacturing and less than half of it in the rural countryside (Banister, 2005), but the final organisational and geographical structure of the fashion business reflects - beside the labour cost - a very complex reality made by the quality level of the sourcing operations, the structure of the supplying country and capital availability, responsiveness, trade regulations and so on. As far as the labour force is concerned, many East European countries present a good educational level and professional training of the employees, piecework remuneration is rather frequent, allowing a direct effective control over the work force, trade unions and shop stewards are almost absent.

During 10 years, OPT has acted as an indirect protection for the EU's textiles and clothing industry. Under this regime producers are forced to use fabrics of Community origin to benefit from the system and East European producers are encouraged to move towards OPT transactions to get the dutyfree treatment for the final products re-imported into the EU. At present EU trade with accession countries is completely free of duties and the outward processing clause is used for fiscal reasons.

\footnotetext{
${ }^{7}$ In 1994, east European partners have been granted zero-duty access to the EU market for all 39 textiles and clothing categories covered by the EU's new OPT regulation, thus gaining preferential status in comparison with other OPT exporters to the EU. At the same time, the general trade regime in textiles and clothing allows MFA-type quota restrictions on direct exports of a considerably larger number of products than for OPT exports from eastern Europe. The direct exports subject to quotas also face customs tariffs.

The Indian ambassador to the WTO, Mr. S. Narayanan, recently told European Parliamentarians at a public hearing in Brussels, that the EU plans to remove quotas on these items from countries with whom the EU has preferential trading arrangements, would "adversely affect textiles and clothing exports from other developing countries"
} 
The low-labour cost in East Europe could probably be maintained over the short and medium-term, but over the longer-run the lower wages are bound to rise upward to West European levels. Growing labour costs may thus lead to the EU's offshoring operators shifting to lower labour cost countries, among whom the constituents of the former Soviet Union are beginning to play an important role.

Shifts between outsourcee countries are frequent and take place rather quickly, as the recent history shows. When Portugal joined the EU in 1986, and during the transition period to membership, the country attracted a lot of offshore apparel production. When the low labour costs attraction weakened or disappeared, the EU's outsourced operations shifted to North Africa, Turkey and Yugoslavia, and later to East Europe. By the early 1990s employment and output were falling in Portugal, particularly because German retailers switched orders to East Europe: exports from Portugal to Germany fell sharply and clothing employment in Portugal declined by almost 25 per cent between 1991 and 1995, from 431.000 to 332.500 (Thiel, Pires and Dudleston, 2000:116). Recently, from 2001 to 2003, Poland has registered a sharp decline of apparel exports towards EU-15 and from 1997 to 2002 employment declined by 37\%, from 400.000 to 253.000 employees, a worse result than in the same period France and Germany (European Commission, 2005).

\section{I.3. Consequences of Continental Europe entering the Globalizing World}

Foreign direct investments and subcontracting both split the process of income generation from income distribution and from employment creation as the three phenomena take place now in different territories. This is why, in Europe, there is currently much concern about the delocalisation of industries to low-cost production locations in Asia and in Eastern Europe. This process is rapidly extending to previously sheltered sectors of European economies and labour markets, notably high-skill services, as medical and "information technology" services (Jepsen and Pascual, 2004). The concern is that competition from these countries will exert downward pressure on pay and working conditions in the advanced economies and will inevitably end up with increasing unemployment. The East-ward move of European firms' production seems to provide support to the common view that the enlargement proceeded without the construction of a solid social protection system in the new member states, so that Western European countries are confronted with wage and social dumping. The new wave of competition brought about by globalisation has come to be superimposed onto the challenges that the European firms had to face since the launch of the single market, through successive waves of enlargements, up to the last enlargement to the Eastern European countries.

There is concern over the perceived transfer of "good" low-skilled manufacturing jobs from developed countries to developing countries. The issue here is not only about the loss of jobs, but also that these have been replaced with "bad” jobs in 'sweatshops' producing for export in developing 
countries (as well as in developed countries for local consumption). This raises the issue of unfair trade and social dumping.

A case in point is the so called Bolkestein directive, with reference to the EU market ${ }^{8}$. Among other things, the directive puts forward two principles for the completion of the internal market: the commitment to a free market for goods and services, with the abolition of licences and requirements deemed unnecessary, and the principle of the country of origin. The directive first of all wants to prohibit all kinds of obstacles for which no compelling reason of general importance exists and that slow the establishment of a company on the territory of a EU Member State. The impact will be particularly perceptible in services as the health care. And should this happen, the government would loose an important tool of employment policy relating to people welfare. The "country of origin" principle entails service providers only being subjected to the national provisions of the country of origin, and not to the laws of the country where the services are provided. This comes down to a legal incentive to move to countries with the least strict legislation at social, fiscal and environment level, and the setting up of fictitious companies which at reduced prices will be able to spread from their registered offices over the whole territory of the Union.

The recent evolution of the German labour market shows clearly some effect of the increasing outsourcing trend. Contractual wages have increased more than actual wages. The difference is to be traced in the "exit clauses" that allow firms to pay wages lower than contractual wages. Trade union ability to contrast this practice is weakened by the threat posed by German firms outsourcing the labor-intensive parts of their production chains to the East and curtailing their investment in Germany (Geishecker and Görg, 2004). If these developments are unchecked and extended with the "country of origin" principle there will be enormous pressure on countries with social, fiscal and environmental standards with a popular move that can eventually jeopardize the social consensus on the very project of European integration.

Many theoretical and applied economists have studied this phenomenon in depth. Bughin and Vannini (2003) and Lorentowicz, Marin and Raubold (2002) have centred on the effect of German FDI in Eastern Europe in the '90s, on the consequences on skilled/unskilled wages and on the unionisation of the labour force. Most researchers agree on the advantage multinationals have over trade unions when negotiating wages, due to the fact that they think globally while unions are still planning at the national scale.

\footnotetext{
8 The European Commission has presented for approval by 2005 the proposal for a Directive on the internal market of Services (COM 20042 final - 2004/0001 COD), known and referred to as Bolkestein Directive. According to the European Community Treaty, article 251, it has to be adopted jointly by the European Parliament and the Council under what is known as the co-decision procedure.
} 
The European Social Model $^{9}$ is put under threat also by the effects of contemporary migration flows entering the European labour market. In the 1980s, Southern Europe changed from being a region of emigration to one of immigration. Immigrants found work in the informal economy, at the beginning mostly in agriculture, spreading afterwards in the services and in many sectors of manufacturing, so that foreign workers rapidly became an important feature of Southern Europe labour markets.

The general attitude is one of alarm at what appears to be an unstoppable flood of people escaping poverty, competing for jobs with local workers, inflating the level of unemployment and applying downward pressure on wages. Popular alarm has put to the test the proposition that, although the overall unemployment rate in Europe is still high, there is demand for migrant workers at the lowest levels of the occupational structure, and that ethnic and racial segregation substantially lessens direct competition with national workers (Reyneri, 2003). The question is whether the Europeans need to maintain low-pay, low-quality jobs within a guaranteed segment of the labour market, while the European Social Model is built on a vision of a uniform labour market and egalitarian income distribution. This has to do both with the skilled-unskilled divide within the "native" workers, and with the increasing inflow of legal and illegal immigrants. Labour shortages in specific sectors notwithstanding, a still very high unemployment rate in the weakest segments of the labour supply, act as an irresistible pull factor on migrant flows from many parts of the world.

Care female workers, in a context of ageing population, provide a typical example. The female component in the immigration flow is acquiring an importance and a visibility totally unknown before. Most of this flow is attracted by an unfilled demand for services, especially personal services, i.e., looking after children and the elderly, both within the family or in private and public institutions. The "care drain", as resort to immigrant female labour for care services, is a paradoxical result for a system built on the notion of social welfare, but is by now a global phenomenon, with many different country varieties and specificities.

\section{Italian Firms in the International Market}

\subsection{Italy's External Position}

Since the reconstruction, after the Second World War, Italy has always been an open economy integrated in the international economy. Exports and imports in goods and services over GDP are in 2004 are 52\%.

\footnotetext{
9 The European Social Model is a concept that both reveals and hides. In fact, when comparing national welfare and employment systems in Western Europe to the US, there are broad differences. The "average" national welfare and employment system in Western Europe, broadly conceived, is broader and more generous; wage and income distributions are generally more equal; and labor, generally although not without exceptions, tends to be more organized, more powerful, and more incorporated into policymaking in Europe than in the US. However, the term "European Social Model" conceals the wide differences existing between national welfare and employment systems in Western Europe (Esping-Andersen, 1996).
} 
About 30\% of Italian exports is represented by small firms with less than 50 employees, 27\% firms between 50 and 250 employees; firms with more than 250 employees account for the remaining 43\%; the number of exporters of the first group, small firms, account to $92 \%$ of total exporters (ICE-ISTAT, 2005:part V). During the last decade the weight of the micro and macro firms on the export total value has remained constant. Small exporters are mainly concentrated in the northern regions of the country, particularly in the North East.

Balance of payment data on direct foreign investments underline that Italian firms are rather backward in comparison with firms of other industrial countries of approximately the same size and the same degree of development, and that foreign firms have a scant interest to invest in Italy (United Nations, 2003: Annex table B.5).

On the whole, information on the internationalization of Italian firms is abundant but fragmentary and probably incomplete. Data on exports available from ISTAT and from CNEL on multinational firms present a satisfactory description only for exports and direct foreign investments. Different sources, as firms case studies or anecdotal reports of non specialized papers, speculate that internationalization of the Italian economy is a much more wide and complex phenomenon: a large part of Italian firms foreign activity is based on some "in-between" form with respect to direct investments and exports, as commercial agreements and technical cooperation. These "light" forms of internationalization do not give rise, at least directly, to statistical measures on commodity transit or to capital flows and this makes them "diaphanous" to the official statistics and rather hard to measure: a scarce consideration by the international trade scholars, not only Italian and not only interested to the empirical aspects has followed.

Almost all the information on direct investments of the Italian firms is generated by the CNEL-Reprint study. According with the latest data relating to the years 2000-2004 foreign firms participated by Italian firms are 15.000 with 870.000 employees, $17 \%$ of the total domestic employees in manufacturing. The quota has increased from $9 \%$ in the early nineties to $14 \%$ by the end of the nineties to the present $17 \%{ }^{10}$. Italian firms are in control of $80 \%$ of these foreign firms (measured by their employment).

The most internationalized firms belong to the automotive sector and the result is due mainly to Fiat. More than $1 / 3$ of the employees in electronic and specialized mechanics is now in firms outside Italy, due to the sector need of continuous transfer of technology. On the whole the sectors more involved in the productive internationalization are the sectors characterized by strong scale economies. Traditional sectors as textile, knitting, apparel, leather, shoes, furniture and wood are the sectors that less have invested in foreign firms. This result is contrasted by empirical evidence according to which delocalization has concerned mainly firm in the traditional sector,

\footnotetext{
${ }^{10} 2004$ data from the database CNEL, R\&P (Politecnico di Milano) are from the courtesy of prof. Sergio Mariotti.
} 
particularly interested to the labour cost reduction, with low capital investment. Again the delocalization of the traditional sectors is organised through a network of foreign firms to which is delegated the manufacturing of single components. This is probably prevalent due to the small average firm dimension, not entirely fit, from the management and organizational point of view, to establish complex technological relations and particularly not interested to establish direct foreign investments.

Direct investment data seem to underestimate the degree of internationalization of the Italian economy. In recent years a key turn in the analysis has been provided by the evaluation of the so-called intra-industry trade. Some authors have based their analysis on the outward processing trade flow data, others have examined import and export trade flows at a high level of disaggregation in order to estimate the change in the trade structure along the different phases of the productive global value chain (Conti and Menghinello, 1998; Schiattarella, 2003; Corò and Volpe, 2003). Research results seem to confirm other country studies and underline that a deep change in the structure of trade is under way, intra-industry trade gaining importance over the total trade value. Firms use imports and exports to move different phases of production in different countries according to the relative profitability. Many firms, not necessarily only the big multinationals, are redefining their core competencies to focus on innovation and product strategy, marketing and the highest value-added segments of manufacturing and services, while reducing their direct ownership over "non-core" functions such as generic services and volume production. Contrary, a lot of outsourcing is originated by small and medium size firms and small size firms take up large part of the supply as well, with negligible direct investments.

Half of all the exporters practice simple strategies, finalized to establish trade partnerships in order to sell and market the product abroad while only a minor number of firms deals directly with the internationalisation of the productive activity.

Capitalia sample data, regularly collected since a decade, provide some important evidence in order to understand the "light forms of industrialization". Firms can be classified according to exports, commercial foreign partnerships, foreign investments and productive partnerships. The first two classes represent direct sales and marketing strategies and are implemented by many firms irrespective of the size, while the other two are positively oriented to production and are limited to large firms. Exporters in general - implement also marketing strategies and take advantage, in the majority of the situations, of local traders without a direct involvement of the Italian firm. Direct investments and productive strategies are instead substitutes (Bugamenlli, Cipollone and Infante, 2000: 360). Italian firms having a productive partners are more numerous than firms investing abroad, belong mainly to the high tech sectors and the partners are generally firms established in the more industrialized countries.

A second part of Capitalia sample investigates delocalization directly. The largest part of total delocalization process interests East European countries, $51 \%$, China and India are marginally affected, $17 \%$. Outsourcing is more 
relevant in the traditional sector, apparel-shoes-furniture. Traditional sectors and specialized suppliers, mechanics and machineries, delocalize mainly in Eastern Europe and China while high tech sectors in the industrial countries (Europe, the States and Hong Kong). The inducement to outsource abroad is always the low labour cost and the need to face price competition. For high tech sectors and sectors characterised by economies of scale (automotive, metallurgy) the proximity of the sale market is also important.

Sectors differ widely for the position along the chain of the outsourced activity. The outsourced activity consists of ready for sale products for the high tech sectors and scale economies sectors, and commodities are sold mainly in the same market where the production plant is located or in neighbouring markets. Specialised suppliers and traditional sectors outsource mainly intermediate commodities, that are re-imported to be completed. In such a case the re-imported intermediate product is generally manufactured in the Italian plant. Ready made traditional products supplied from foreign outsourced manufacturing, are mainly sold in the Italian market.

Table 3. Italian Firms Outsourcing: Importance of Relative Components

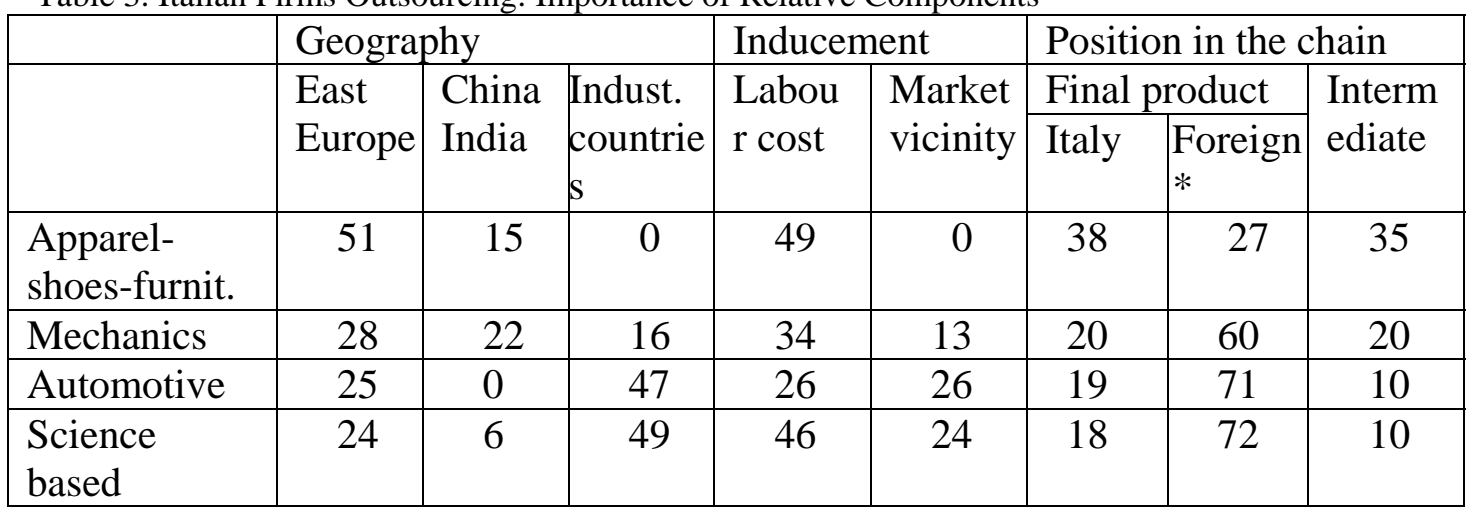

Source: Capitalia: Tabes D74, D77, D89. Values referred are reported to percentage.

*Foreign means sold in the same country where the plant is located or directly to other countries (always outside Italy)

\section{II.2. Italy Sub-contracting in Rumania}

The delocalization of Italian firms has privileged Rumania among the East European countries. This preference is explained by the substantial difference in labour $\operatorname{cost}^{11}$ and by the geographical proximity of the two territories. In particular almost half of the delocalization process in Rumania is originated in the Veneto. The Veneto is a region of the Italian Nord East

\footnotetext{
${ }^{11}$ Graziani (1998; 2001) studied the cost of labour structure in several European countries and reached the conclusion that the cost saving due to the delocalization process are to be estimated at $50 \%$ for Germany and at $40 \%$ for Italy. The unit labour cost in the apparel and shoes sectors in Rumania is about $1 / 7$ of the labour cost in Italy, but due to the inferior productivity the cost difference can be estimated to reduce to $50-60 \%$ still a large gap. In such conditions the delocalization process will continue at growing speed and will be accompanied by an increase of product quality, which is a fundamental element to grant better competitiveness for the Italian brand productions in the high segment of the fashion world market.
} 
with high manufacturing activity, mainly devoted to traditional productions and mechanics and is positioned as the fulcrum around which the process of the EU enlargement towards the East has turned.

The process of delocalisation is the combined result of the centrifugal forces deriving from the global search for continuously less costly production sites and the need to get closer to the core markets, in order to cope with increasing market uncertainty due to shortened fashion cycles and reduced production batches. The opening of the East and Central European markets in the early nineties has provided a balance between cost and shortened delivery time. Small Veneto firms first outsourced in Poland and Hungary, and now in Romania, Ukraina and Bulgaria.

Veneto apparel firms outsourced domestically to local small laboratories since the early eighties, as the district organized itself in a flexible network of production, putting out large part of production phases (sewing, ironing, dying and so on) so that employment by apparel final firms recorded a constant decline, while employment by artisan firms increased and compensated. The early nineties starts a new trend because both small artisan firms and final large firms show a drastic decline in employment, while succeeding in keeping the sector value added constant (at constant prices) as the result of outsourcing to the East European countries, and to India, Bangladesh and China (Crestanello and Dalla Libera, 2003; Corò and Volpe, 2003; Gianelle and Tattara, 2006). While important producers (Benetton, Stefanel, Diesel, etc) in the Veneto still retain important stages of production at home - logistic, design, planning - there is an increasing flow of imports, of semifinished and finished goods particularly from the Far East, sold directly to retailers.

Rumania plays a particular role in the Veneto delocalization process because the country had a significant presence of textile, knitwear, and shoes production as a part of the Soviet System, the same sectors where the Veneto has a traditional strong specialization and because Veneto production characteristics make outsourcing rather easy. Specialized labour is abundant in Rumania as the country after 1990, has undertaken a very deep restructuring process that saw, in apparel and leather production, the loss, in a decade, of several hundred thousand employees ${ }^{12}$

Capital flows into Rumania have been fully liberalized since the very beginning. Direct investments on Rumania have grown from 3\% of gross national income in the period $1990-96$ to $17 \%$ in $2004^{13}$. Investments, in large part, depend from the outsourcing process of big foreign firms in manufacturing (Daewoo, Renault, Coke, Shell, Panasonic) in distribution, in banking and in services (Metro, Carrefour, Billa, Unilever, Continental and the main European banks). Out of 12.366 Italian firms active in 2002 in Rumania, 2.038 have a 'Veneto origin', i.e. 16,5\% of the total. ("Survey on the Entrepreneurial Veneto Presence in Rumania"). In 1996 the first 25 Rumanian productive units controlled by foreign firms in manufacturing had

\footnotetext{
${ }^{12}$ Total employment in manufacturing has bees cut by 50\% in 10 years, and employment in textile firms has dropped of more than 200.000 employees. See Insse 2003.

${ }^{13}$ Rumania ranks fifth among Eastern Europe countries as far as the absolute value of direct foreign investments is concerned. Capital outflows are trifling.
} 
a turnover of around 2000 millions \$. This amounts to $6 \%$ of the total turnover produced by private Rumanian firms ${ }^{14}$. Italian direct investments are third on the ladder of foreign direct investments and account for around 50.000 workers. This is just a small fraction of the Rumanian workers working for manufacturing Italian goods, when full account id taken of all the internationalization process.

Rumania exports and imports have grown in the last decade at an annual rate of $12 \%$, the trade quota with the European Union has remarkably increased and is now around $65 \%$ of the Rumanian total trade. OPT accounts for $60 \%$ of all Rumanian exports and 32\% of imports and OPT trade is related mainly to apparel and footwear. Large part of the production of the Rumania industries is therefore dedicated to the transformation of raw materials and semi-finished goods, mostly imported from Western Europe and re-exported towards these same countries at a more advanced level of production.

In 2000-2004 imports of apparel from Rumania have paralleled imports from China while Romania is by far the most important producer of shoes imported in Italy.

The prevalent delocalization form in respect to Rumania is sub-contracting. Italian textiles and tanned leather can be easily imported in Rumania to be transformed according to the outward processing trade regime. Trade data provide immediate evidence of production fragmentation between Italy and Rumania. Comparing Italy's apparel and footwear imports from Rumania and Rumania textile and leather imports from Italy (table 4) the role of Rumania as a manufacturer of Italian textile and leather products appears in full evidence (similar to Tunisia, an outsourcing market as well). in outward processing trade.

Table 4. Italy trade flows. Textile-Apparel-Leather-Shoes. 2004. Million \$

\begin{tabular}{|l|r|l|l|l|}
\hline & Import & Export & Import & Export \\
\hline & $\begin{array}{l}\text { Apparel } \\
(84)\end{array}$ & Textile (65) & $\begin{array}{l}\text { Footwear } \\
(85)\end{array}$ & $\begin{array}{l}\text { Leather } \\
(61)\end{array}$ \\
\hline Total & 11.290 & 15.406 & 4247 & 4406 \\
\hline China & 2065 & 198 & 401 & 221 \\
\hline Romania & 1563 & 955 & 1118 & 416 \\
\hline Tunisia & 901 & 616 & & \\
\hline
\end{tabular}

Source: UN: comtrade. Sitc 3 classes in brackets

The estimate of the number of Rumanian workers employed to manufacture apparel and shoes products re-imported into Italy is 60.000 with reference to the Veneto and 120.000 to Italy. The latter represents that is $27 \%$ of total Rumanian sector employment.

Manufactured relations require the supply of some, few, production phases, although the delocalization of single units can incur in diseconomies of

\footnotetext{
${ }^{14}$ Rumanian turnover in 1998 was 713400 billion Lei, whose 62\% is related to the private sector. See National Accounts. Gross domestic product by category of resources. $\underline{w w w . i n s s e . r o . ~ T h e ~ r a t e ~ o f ~ e x c h a n g e ~ i s ~ t h e ~ a v e r a g e ~ y e a r l y ~ r a t e ~ f o r ~ 1999, ~} 1 \$=15.332$ lei.
} 
scale and organizational costs. These costs are reduced if the number of phases outsourced abroad is numerous.

The performance of apparel and shoe Rumanian sub-contractors producing for foreign brands does not seem to be adversely affected by their being part of a foreign chain; profits of exporting firms (sub-contractors) are around average and losses are, relatively, very limited. It seems that subcontracting is less risky than producing for the domestic market.

The result of this performance is underlined by the relative increase in the number of manufacturing employee increase for the three years 2000-2002, positively over the average (Insee, 2003).

\section{II.3. Sub-contracting in East Europe: The Benetton Group}

The core business of the Benetton Group is clothing. The group production has a strong Italian character whose style; design expertise and passion are seen in the United Colours of Benetton and the more fashion-orientated Sisley brands, and in sportswear brands Playlife and Killer Loop.

The Group produces over 110 million garments every year, over 90\% are sold in Europe. The entire production is coordinated by a high-tech facility at Castrette (Treviso, Italy). The retail network of 5,000 stores around the world is increasingly focused on large floor-space points of sale offering high quality customer services and now generates a total turnover of 1.9 billion euros, net of retail sales. Direct employment is around 7 thousand people.

A constant commitment to innovation, a crucial factor for development, has always characterized the Group's business organization, from communication to information technology, from research into new materials to integrated logistics. Special attention is given to innovation in production, where all systems and equipment are frequently renewed.

One of Benetton's innovations at the very beginning, in the sixties was a particular dying system, dying the raw product, just to meet the fashion requirements, and now the most relevant innovation is the production of a complete, seamless sweater in half an hour, thanks to modern knitting machines and in house software development.

From the very beginning, Benetton decided to maintain direct control of the logistics phase and invested heavily in automating logistics processes in order to achieve total integration within the production cycle, from customer orders to packing and delivery. Flat and hanging garments are automatically sorted. Over 110 million items a year are packed into boxes and sent directly to the distribution through a tunnel of approximately one kilometer in the general automated distribution system at Castrette. This system covers an area of 20,000 square meters, with a total capacity of 400,000 boxes, and is able to handle 40,000 incoming/outgoing boxes daily with a workforce of only 24 , compared to the 400 people normally required in a traditionally 
organized operation. The finished product is sent directly to the group's 5,000 retail outlets in 120 countries worldwide.

The tendency to establish abroad some productive platforms started years ago and Spain came first. Spain was followed by Tunisia, Croatia and Hungary. Some marginal production is carried out also in Brazil and India. In these markets and in Turkey the brand operates via licensing on specific items and sells the whole range of products.

Production (110 millions items) was traditionally made in Italy, mainly in Veneto; the large majority of production was outsourced to sub-contractors; around 750-800 subcontractors in the early nineties. Benetton production was traditionally based on direct production and outsourcing in small, medium and large sub-contractors in Veneto. Relations with suppliers were considered stable and supplier worked almost entirely for Benetton.

To day only $30 \%$ of the Benetton production is realized in Italy, the remaining $70 \%$ is manufactured abroad; the majority, $26 \%$, is obtained in Hungary, $14 \%$ in Croatia, $15 \%$ in Tunisia and the rest in Spain. The importance attributed to Hungary to set up the largest productive platform outside Italy is no surprise as was actually Hungary who led the outsourcing wave towards Central Europe, having invested large sums in countries like Romania and Ukraine; there are about 4,000 Hungarian-owned companies in Romania and a third of them catering to outsourcing.

Benetton sub-contractors in Italy have declined in number, from 740 to 520 but the decline in number reflects a larger decline in the level of activity as sub-contractor nowadays are probably working for other brands as well, while in the nineties were operating exclusively for Benetton.

To organize the sub-contractors network in East Europe, Benetton has built an important hub in Hungary; Benetton employees working there are 380 and provide leverage to 50 direct sub-contractors; the whole direct and indirect network is estimated to affect 3000-3300 workers, spreading from Ukraine to Bulgaria.

The role of East Europe in the total Benetton production is growing fast and will reach soon $80 \%$. Benetton is now looking with great attention to East Asia. The company in the last year has strengthened its sourcing office in Hong Kong planning to start production with the sports system brands like Killer Loop, Playlife and some of the kids wear. The small factory that Benetton owns in India has been re-launched and the firm is working very hard to get samples and quotations from Chinese partners and start a new venture there. The plan is to raise the Asian production quota to $20 \%$ of the total by 2007.

The delocalization process is the main responsible for the cost reduction realized in the last couple of years according to Benetton Financial Statement (November 2004). The cost reduction at the consolidated level, attributed by the managers to the delocalization process, in one year has reached 12 percent (2004 over 2003) ${ }^{15}$. According to the Benetton director

\footnotetext{
15 "By far, the most important driver of the decrease is the quickly increasing manufacturing delocalization. The increasing delocalization added benefit of approximately 16 million on our nine-month operating income, and the localization index rose from 59 percent in 2003 as an average in the first nine months to 67 percent as an average in the first
} 
S. Cassano delocalization had a non secondary advantage of moving the cost structure from being focused on fixed costs into variable costs, and governing a much more flexible productive structure.

Table 5. Structure of the Benetton suppliers

\begin{tabular}{|l|r|l|r|r|}
\hline Country & Year & $\begin{array}{l}\text { Production pahses } \\
\text { directly owned by } \\
\text { Benetton group }\end{array}$ & subcontractors & $\begin{array}{r}\text { n.of pieces in } \\
\text { millions }\end{array}$ \\
\hline Tunisia & 1994 & $\begin{array}{l}\text { priting and dying, } \\
\text { special.jeans }\end{array}$ & 80 & 21 \\
\hline Hungary & 1998 & $\begin{array}{l}\text { Cad placement and } \\
\text { cutting, printing }\end{array}$ & 50 & 30 \\
\hline Croatia & 2004 & & & 70 \\
\hline Others & & & & 30 \\
\hline Italy & & & & 108 \\
\hline Total & & & & \\
\hline
\end{tabular}

\section{Rumania, an Emerging Hub and Financial Cooperation}

In the modern globalization process sub-contracting is very relevant and supplements to the importance of foreign direct investments. Foreign direct investments provide a stable flow of resources: outsourcing has no sunk costs and shares much of the unstable character of short-term capital flows. The reverse of the coin is that what means instability for the sub-contractor means additional strength for the head of the chain through increased flexibility and production costs further reduction.

Romania liberalized foreign investments and regulations governing the conversion of domestic into foreign currency in the early nineties, well before trade liberalization. The uncertainty of the economic situation, the slowness of the privatization process, delayed foreign financial capital that entered Romania quite late in relation to other countries in transition, by the end of the nineties (RNB, 2002).

What is important from the point of view of the global economy is that the inflow of foreign capital imposes a deflationary environment on the Rumanian economy, and this has been superseded by the procedures required for entering the accession process that will lead Romania to become a EU member by 2007.

The deficit of the government and its expenditures financed with borrowing have been substantially reduced, curtailing the most needed public spending.

nine months of 2004. Let's go to the breakdown of operating income by activity, and let's focus on the casual segment making 100 percent of the total drop. The main drivers of this decrease are all located at the level of gross profit. Casual gross profit decreased by 30 million, compared with the previous year. The first factor is a negative currency impact accounting for approximately 7 million. Then we have two positive effects related with the increase in year-to-date volumes, and with that increase in manufacturing delocalization. However, these two positive effects only partly balance the negative price mix affect and the combination of all of these factors result in this decrease in casual gross profit by 13 million” (Benetton 2004 a, b). 
Financial interests are against deficit financed spending for several reasons (Kalecki, 1976; Chandrasekhar and Ghosh, 2004 ${ }^{16}$ ). Deficit financing is potentially inflationary through the creation of additional liquidity and since government spending does not reflect a market logic, the use of debt to finance the government autonomous spending is seen as introducing into the financial market an autonomous player altering the rules of the game. Additionally if deficit spending leads to a substantial buildup of the state debt and interest burden, the financial community fears that the State might intervene in the financial markets to lower interest rates and reduce financial returns.

As a substantial part of Rumanian exports are the result of outsourcing operations, the country imports cannot be kept at too a low level without engendering exports. Surplus is the result of keeping trade imbalance within modest margins before a substantial inflow of current transfers, mainly in the form of remittances and short term and portfolio capital inflows. As the result of the deflationary fiscal stance adopted by the government, Rumania records a limited deficit in her current account and a substantial reserve stock $^{17}$.

In the framework provided by the present international monetary system, facing the huge US unbalance, Rumania represents the situation of the developing countries as a group. Developing countries do not require large capital inflows to finance their balance of payments, but such inflows do occur, particularly in the form of private foreign investment. Such capital inflows then either go out as "other net investments" or are accumulated as reserves that are eventually invested in large measure in US Treasury bills. That is, private capital flows into developing countries to earn lucrative returns, and this capital then flows out as investment in low interest Treasury bills in order to finance the US balance of trade deficit.

If a country is successful in attracting financial flows, the consequent tendency for its currency to appreciate - as is seen in Rumania since the first months of 2005 - endanger the transformation role of the economy as it increases the relative cost of production, forces the central bank to intervene in the currency market to purchase foreign currency and prevent excessive appreciation. The consequent build-up of foreign currency assets, while initially sterilized through the sale of domestic assets, especially government securities, soon reduces the monetary policy flexibility by the central bank and leads to an increased deflation.

Eventually, financial liberalisation that successfully attracts capital flows, increases vulnerability and limits the policy space of the government. The real benefit of such flows is derived by the US government, which, being the home of the reserve currency can resort to large scale deficit financing. The recent financial crisis in Asia and in Latin America conveys the lesson that integration into international capital market is possibly more difficult than successfully insert oneself into an international trading system. The

\footnotetext{
${ }^{16}$ The Romania example fits squarely with the analysis of the international monetary system provided by Chandrasekhar and Ghosh, 2004.

17 Foreign direct investment represent, since mid nineties, the major source of current account financing.
} 
Asian crisis is probably the most recent proof that East Asian economies succeeded as trading partners and grew at very high rates, but did not do so well in becoming part of the financial capital market. As a result developing countries should not be "pushed or pressured into premature financial liberalization," as is suggested by the WTO authorities and industrialized countries and as was the case of East Europe economies.

The basic problem for the country "at lower development stage" consists in transiting from the the more simple to the more complex segments of the global value chains, becoming active part in the production fragmentation that takes place across the national borders. This means to be able to offer more parts of the production process and evolve gradually towards a supply set able to offer the entire manufacturing process, from the raw materials to the final product. For example in Rumania apparel firms, one vertical bottlenecks (inside-the-chain bottleneck) is represented by the lack of high capital and technologically sophisticated dying plants, while an horizontal bottleneck (outside-chain) is due to the lack of the domestic supply of machine and apparatus, which means also lack of domestic maintenance capability (Crestanello and Tattara, 2005).

To move to higher positions in the global value chains is the only way to stabilize the manufacturing process and to allow the country to face a rising cost of labour without assisting to a customers' migration towards cheaper locations in Ukraina, Moldava and Bielorussia.

As short term capital flows, subcontracting needs to be governed. The economic history of East Asia that tells us that several countries were able to accomplish this process and went from sub-contractors to suppliers of finished products on custom order (Gereffi, 2002). But they did it in a framework that saw the state intervention in many circumstances, with an explicit industrial policy, lastly the Taiwanese example with the creation of a domestic semiconductors industry. This step is eventually open also to the East European countries but the positive result - if there will be one - is not a free-trade automatic result but a governed one; it does find support in a policy open to foreign trade, but is something apart from a policy of financial market complete liberalization. 


\section{References}

Banister,J., 2005, Manufacturing Employment and Compensation in China. BLS Bls research paper, due to appear in Monthly Labour Review, July 2005.

Benetton Group, 2004a, Earnings Conference. Fair Disclosure Wire.3/30/2004

Benetton Group, 2004b, 9 Months 2004. Results Conference Call. Fair Disclosure Wire; 11/12/2004

Bugamelli M., P. Cipollone, L. Infante, 2000, "L'internazionalizzazione produttiva delle imprese italiane negli anni novanta”, Rivista italiana degli economisti, 5 n. 3.

Bughin, J.,Vannini, S., 2003, Unions and the Welfare Impact of Foreign Direct Investment - A Wisdom Extension, Labour, Vol. 17, pp. 285-298, June

Chakravarthi R.. 1995, East Europe cautioned on Ecu-Opt dependence. <www.sunsonline.org/trade/process/followup/1995/12060095.htm >

Chandrasekhar C.P., Ghosh J., 2003, The New Structure of Global Balances. <www.networkideas.org/news/nov2004/news11_Global_Balances.htm>

Conti G. Menghinello S.,1998, Modelli di impresa e di industria nei contesti di competizione globale: l'inetrnazionalizzazione produttiva dei sistemi locali del Made in Italy, L'industria, 2, p. 315-348.

Crestanello P., Dalla libera P.E., 2003, La delocalizzazione produttiva all'estero nell'industria della moda: il caso di Vicenza. Economia e società regionale,_2, 545.

Corò G. e M. Volpe, 2003, Frammentazione produttiva e apertura internazionale nei sistemi di piccola e media impresa, Economia e società regionale. n. 1. vol. 81

De Cecco, M.,1997, The Gold Standard, In Marcuzzo M. C., Officer L. H., Rosselli A. (eds), Monetary Standards and Exchange Rates, Routledge, London and New York, p. 62-77.

Edelstein, M., 1982, Overseas Investments in the Age of High Imperialism, Columbia University Press, N.Y.

Esping-Andersen, G.,1996. Welfare States in Transition. Sage Publications. London.

European Commission. 2005, The Textiles and Clothing Industries in an Enlarged Community and the Outlook in the Candidate States. Part. 1

Feenstra R, 1998, Integration Trade and Disintegration of Production in the Global Economy, Journal of Economic Perspectives, 12: 31-50.

Feenstra R.C and Hanson, G., 1997, Foreign investment, outsourcing and relative wages, in R.C. Feenstra, G.M. Grossman and D.A. Irwin (eds.), Political EconPolicy: Essays in honour of Jagdish Bhagwati, Cambridge Mass.

Fenoaltea S., 1988. International Resource Flows and Construction Movements in the Atlantic Economy: the Kuznets Cycle in Italy, 1861-1913”. The Journal of Economic History, XLVIII.3, 9: 605-636.

Finger J.M., 1975, Trade Provisions for Offshore Assembly and the Exports of Developing Countries. AER vol 85 (338):365-371. 
Finger J.M., 1977, Offshore Assembly Provision in the West German and Netherlands Tariffs: Trade and Domestic Effects. Weltwirtschaftliches Archiv. v.113 (2):237-249.

Fishlow A., 1985. Lessons from the Past: Capital Markets during the 19th Century and the Interwar Period. International Organization, 39.3. Summer.

Geishecker, I., Görg, 2004. Winners and Losers: Fragmentation, Trade and Wages Revisited, IZA Discussion Papers 982, Institute for the Study of Labor (IZA).

Gereffi G. J. Humphrey, T. Sturgeon, 2003, The Governance of Global Value Chains Forthcoming . Review of International Political Economy, November 4.

Gereffi G., 2002. The international competitiveness of asian economies in the apparel commodity chain. ERD Working Paper No. 5 February.

Gianelle C. and Tattara G., 2006, Produrre all'estero e fare profitti in patria: unostudio sulle imprese venete dell'abbigliamento e delle calzature. In Tattara G. Corò G. e Volpe M.. La delocalizzazione come strategia competitiva. Carocci. Roma.

Graziani, Giovanni, 1995, Threats and opportunities for West European industry deriving from trade liberalization with Central and Eastern Europe, in Rumen Dobrinsky and Michael Landesmann, eds., Transforming Economies and European Integration, Edward Elgar, Aldershot, UK and Brookefield, US 168-190.

Graziani, Giovanni, 1998, Globalization of Production in the Textile and Clothing Industries: The Case of Italian Foreign Direct Investment and Outward Processing in Eastern Europe, in John Zysman and Andrew Schwartz, eds. Enlarging Europe: The Industrial Foundations of a New Political Reality, University of California at Berkeley.

Graziani G. 2001, International Subcontracting in the Textile and Clothing Industry, in Arndt S.W., Kierzkowsky H., Fragmentation. New Production Patterns in the World Economy, Oxford. Oxford University Press.

Hummels D., Rapoport D., Yi K., 1998, Vertical Specialization and the Changing Nature of World Trade. Federal Reserve Bank of New York Economic Policy Review (June), pp. 79-99.

Kaminski B., and F.Ng, 2000, Trade and Production Fragmentation: Central European Economies in EU Networks of Production and Marketing. World Bank Discussion Paper.

Keynes, J.M. [1913] 1971, Indian Currency and Finance, In D. Moggridge (ed.) The Collected Writings of J.M.Keynes, vol.1. London: Macmillan.

ICE - ISTAT 2005, Commercio estero e attività internazionali delle imprese . Annuario 2004

Insse, 2003, Statistical Yearbook.Bucharest.

Jepsen M., Pascual A. S., 2004, The European Social Model: an exercise in deconstruction. Working paper

Lorentowicz, A. Marin D., Raubold, A, 2002, Investment in Easter Europe may cause unemployment in Western Europe, Cepr, DP 3514, july.

National Bank of Romania, 2002, Annual Reports 1996-2000. Bucharest. Romania 
O’Rourke K.H. and J. Williamson, 1999. Globalization and History. The evolution of a nineteenth century Atlantic Economy. Cambridge.

O’Rourke K.H., 2002. Europe and the causes of globalization, 1790 to 2000. In H. Kierzkowski (ed.) From Europeanization of the Globe to the Globalization of Europe. Palgrave.

O’Rourke K.H.. w.d. Long distance trade: long distance trade between 1750 and 1914.Mimeo

Obstfeld M. and Taylor A.M., 2001, Globalization and capital markets. NBER Working Papers, n. 8846.

Reyneri, E. 2003, Immigration and the Underground Economy in New Receiving South European Countries, International Review of Sociology 13/1, pp. 117-143

Rossetti S. Schiattarella R., 2003, Un approccio di sistema all'analisi della delocalizzazione inetrnazionale. Uno studio per il settore made in Italy. In Acocella N. Sonnino E.,(eds) Movimenti di persone e movimenti di capitali in Europa, Il Mulino, Bologna, 385-503.

Taylor A.M., 2002, Trade and development: some lessons from history. NBER Working paper s, n. 9326

Thiel J, Pires I and Dudleston A, 2000, Globalisation and the Portuguese textiles and clothing filière in the post-GATT climate In Giunta A, Lagendijk A and Pike A (Eds.), Restructuring Industry and Territory: The Experience of Europe's Regions, Stationary Office, London: 109 - 26

TPI, 2004, European Outsourcing Market Rivals U.S. in 2004. London, 16 January 2004.

United Nations, 2003, Conference on Trade and Development World Investment Report 2003 FDI Policies for Development: National and International Perspectives United Nations New York and Geneva.

Zlotnik, H. 1999, Trends in International Migration Since 1965: What Existing Data Reveal, International Migration, 37:21-61. 